\title{
Somatic Embryogenesis from Young Leaf Tissues of the Sago Palm-Metroxylon sagu
}

\author{
Zaliha Christine Alang*1 and Baskaran Krishnapillay \\ Biology Department, Faculty of Science and Environmental Studies, Universiti \\ Pertanian Malaysia, Serdang, Selangor, 43400 Malaysia
}

(Received September 24, 1986)

(Accepted December 12, 1986)

\begin{abstract}
The sago palm (Metroxylon sp.) is gaining an increasing interest as a source of industrial starch. In terms of calorific yield per hectare, the sago palm is considered to be one of the highest yielding crops in the world. The palm is well adapted to tropical swamplands where no other agricultural crop can grow, and requires minimal maintenance during its growth. Three international symposia $^{1-3)}$ have been held to consolidate and encourage research and to highlight the potential of this underexploited species. Although the palm can be grown from seeds, it is usually propagated from suckers because vegetative propagation results in a more uniform planting. Vegetative propagation in vitro, however, would accelerate the production of quality planting material suitable for plantation establishment.
\end{abstract}

The tissue culture techniques have been used successfully in the propagation of a wide variety of species, including numerous agricultural crops and some forest trees. The three commercially important palms - namely oil palm, date palm and coconut palm - have also been propagated vegetatively in vitro. This paper presents the first report of success with in vitro propagation of the sago palm through somatic embryogenesis from young leaf tissue.

Research began in mid-1984 with emphasis on attaining aseptic explant material from this swampinhabiting species and the determination of suitable explants for in vitro culture. ${ }^{4)}$ Stem apex and unemerged leaves from young suckers were found to be the most suitable tissues for study as they were responsive in culture, and being well protected by outer leaf bases, required minimum sterilization. Tissues were cultured on a modified Murashige and Skoog medium ${ }^{5)}$ containing a variety of combinations and concentrations of auxins and cytokinins with or without $0.3 \%$ activated charcoal. Indoleacetic acid (IAA), $\alpha$-naphthaleneacetic acid (NAA) and indolebutyric acid (IBA) and 2, 4dichlorophenoxyacetic acid $(2,4-\mathrm{D})$ were used at $5-25 \mathrm{mg} / \mathrm{l}$ in media without charcoal and at 50-200 $\mathrm{mg} / \mathrm{l}$ in the presence of charcoal. Kinetin, $\mathrm{N}^{6}-\left(2\right.$-isopentenyl) adenine $(2 \mathrm{iP})$ and $\mathrm{N}^{6}$-benzylaminopurine (BAP) were used at $1-3 \mathrm{mg} / \mathrm{l}$. Media were solidified with $7 \mathrm{~g} / \mathrm{l}$ Difco bacto agar and autoclaved for $15 \mathrm{~min}$ at $121^{\circ} \mathrm{C}$. Cultures were incubated in a 12 -hour photoperiod or in the dark at $28 \pm 1{ }^{\circ} \mathrm{C}$.

After 5 months in culture, several of the explants began to produce nodular structures when transferred to the light after a period of dark incubation (Fig. 1). High levels of 2, 4-D (125-175 $\mathrm{mg} / \mathrm{l})$ and the presence of activated charcoal appear to be essential in initiating the response. The nodular structures were extremely friable and individual nodules could be separated from one another by simply tapping the culture tube. When subcultured, both the original explants and individual nodules continued to produce more of these structures (Fig. 2). Anatomical observation (Fig. 3) and the further development of nodules into plantlets (Fig. 4) following transfer to a medium

*1 Present Address : Biotechnology Department, Faculty of Food Science and Biotechnology. 


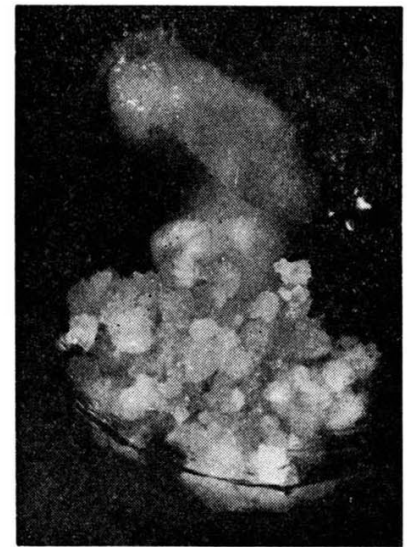

Fig. 1. Nodular structures on leaf explant after 5 months in culture.

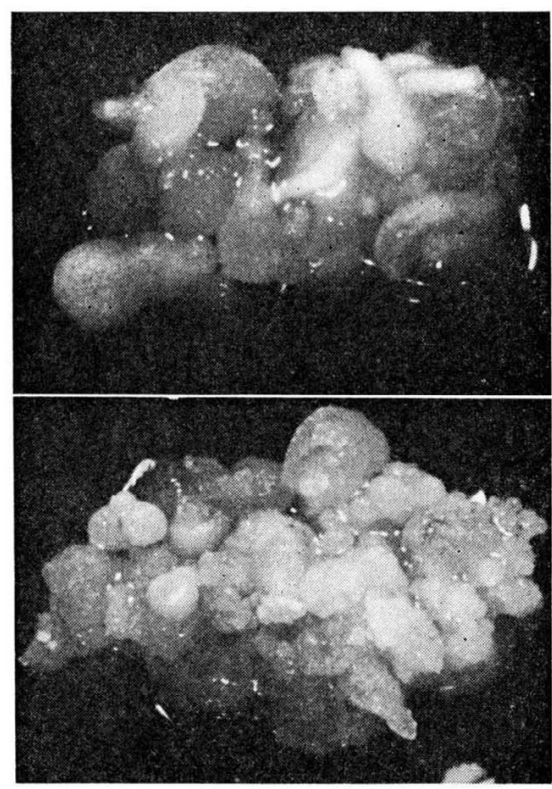

Fig. 2. Proliferation of nodules after 6 weeks in subculture.

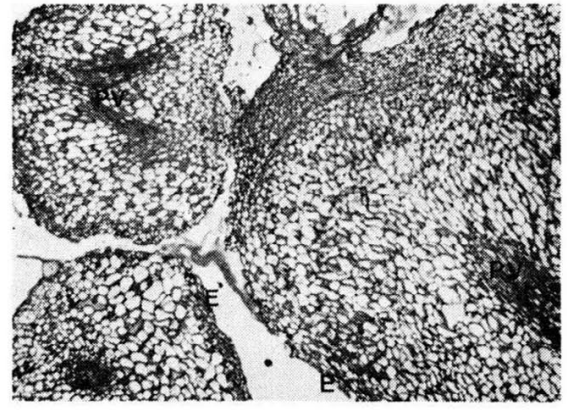

Fig. 3. Section through nodules showing well defined epidermis (E) and provascular strands (PV).
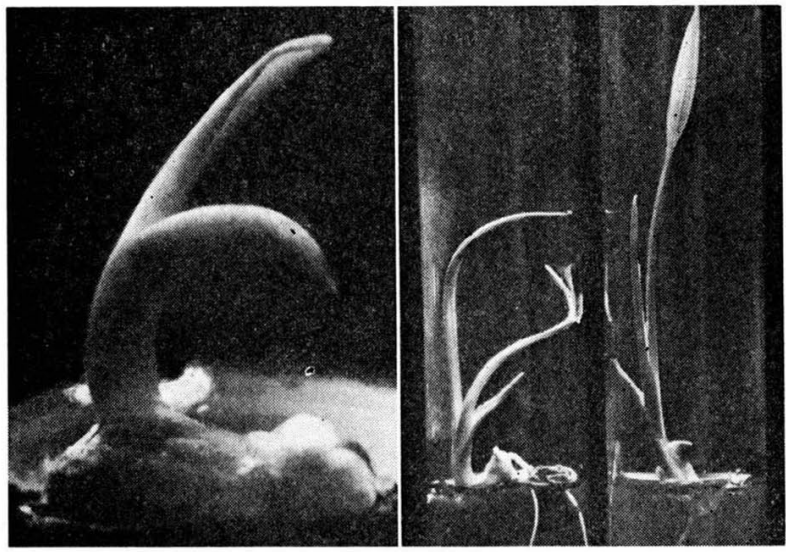

Fig. 4. Nodules develop into plantlets within 2 months of transfer.

containing a lower concentration of $2,4-\mathrm{D}(50 \mathrm{mg} / \mathrm{l})$ in combination with $2 \mathrm{iP}(3 \mathrm{mg} / l)$, suggest that the nodules are somatic embryoids similar to those reported in oil palm, ${ }^{6)}$ coconut $^{7)}$ and date. ${ }^{5)}$ Further research is now underway in our laboratory to optimize the procedure so that embryoids can be obtained under the mildest cultural conditions to avoid any possibility of genetic modification of regenerated plantlets.

The results reported above indicate that it will soon be possible to propagate large numbers of identical sago palms from selected ortets. The establishment of this crop on a plantation basis will ensure a regular supply of trunks for sago starch processing factories, which hitherto have had to rely on the exploitation of natural stands of sago. Moreover, plantation management of in vitro propagated palms is likely to reduce the long immaturity period of the crop, making sago starch 
production a more economically viable concern. Thus the sago palm-once merely a source of traditional foodstuff-may soon become a valuable export commodity for developing countries in the equatorial regions of the world.

We wish to thank Universiti Pertanian Malaysia for supporting this research as part of a full-time postgraduate project, and the Sago Palm Research Foundation of Japan for their interest and encouragement in this work. We also thank Assistant Professor Dr. Shigeru Hisajima, Institute of Applied Biochemistry, University of Tsukuba, for valuable advice on manuscript preparation.

\section{References}

1) Tan, K., 1977. Proc. 1st Int. Sago Symp., University of Malaya Press, Kuala Lumpur.

2) Stanton, W. R., M. Flach (ed.), 1980. Proc. 2nd. Int. Sago Symp., Martinus Nijhoff Publ., Netherlands.

3) Yamada, N., K. Kainuma (ed.), 1986. Proc. 3rd Int. Sago Symp., The Sago Palm Research Fund, Tokyo.

4) Krishnapillary, B., Z. C. Alang, 1986. In "Proc. 3rd. Int. Sago Symp." (ed. by Yamada, N. and K. Kainuma), p. 130-138, The Sago Palm Research Fund, Tokyo.

5) Tisserat, B., D. A. DeMason, 1980. Ann. Bot., 46:465-472.

6) Ahee, J., P. Arthuis, G. Cas, Y. Duval, G. Fuenin, J. Hanower, P. Hanower, D. Lievoux, C. Lioret, B. Malaurie, C. Pannetier, D. Raillot, C. Varechon, L. Zuckerman, 1981. Oleagineux, 36: 113-115.

7) Raju, C. R., P.P. Kumar, M. Chandramohan, R. D. Iyer, 1984. J. Plant. Crops, 12: 75-78.

\section{《和文要旨》}

\section{サゴヤシ若葉由来小塊状カルスからの不定肧形成}

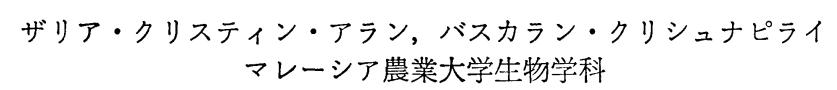

サゴヤシサッカー非展開葉を高濃度 2,4-D と活性炭を添加した培地で暗培養後, 明培養に移したと ころソマティックエンブリオイドと考えられる小塊状カルスが生じた．乙の小塊状カルスは連続的に增 殖可能であった. ての小塊状カルスを $2 \mathrm{iP}$ と低濃度 $2,4-\mathrm{D}$ を含む培地に移すと不定肧を経て幼植物が 生長した. との技術によりサゴャシのクローン育苗が初めて可能となった。 